Tropical Journal of Pharmaceutical Research June 2015; 14 (6): 1057-1062

ISSN: $1596-5996$ (print); 1596-9827 (electronic)

(C) Pharmacotherapy Group, Faculty of Pharmacy, University of Benin, Benin City, 300001 Nigeria.

All rights reserved.

Available online at http://www.tjpr.org

Original Research Article

http://dx.doi.org/10.4314/tjpr.v14i6.17

\title{
Ameliorative Effect of Lecaniodiscus cupanioides (Sapindaceae) Aqueous Root Extract in Loperamide- Induced Constipated Rats
}

\author{
Mikhail O Nafiu', Taoheed A Abdulsalam1, Rukayat $0 \mathrm{Jimoh}^{1}$ and Mutiu I \\ Kazeem ${ }^{2 *}$ \\ ${ }^{1}$ Department of Biochemistry, University of Ilorin, PMB 1515, Ilorin, ${ }^{2}$ Food Security Niche Area, Faculty of Natural Sciences, \\ Mangosuthu University of Technology, PO Box 12363 Jacobs, Durban 4026
}

*For correspondence: Email: mikazeem@gmail.com; Tel: +2348030622000

\begin{abstract}
Purpose: To evaluate the efficacy of aqueous root extract of Lecaniodiscus cupanioidies Planch. (Sapindaceae) against loperamide-induced constipation in Wistar rats.

Methods: Constipation was induced by oral administration of loperamide (3 mg/kg body weight). The constipated rats were orally treated daily either with $50,150,250 \mathrm{mg} / \mathrm{kg}$ body weight per day of the extract or $0.21 \mathrm{mg} / \mathrm{kg}$ bisacodyl (reference drug) for 7 days while the normal control group received distilled water. The feeding characteristics, body weight, faecal properties and gastrointestinal transit ratio were monitored throughout the study period. The activities of acid phosphatase (ACP), alkaline phosphatase (ALP), aspartate aminotransferase (AST), $\gamma$-glutaryltransferase (GGT) and lactate dehydrogenase $(L D H)$ were also determined in the serum of the animals.

Results: There was significant decrease $(p<0.05)$ between normal and constipated rats in the number of faecal pellets (54.06 and 45.43) while body weight increased (124.45 and $135.38 \mathrm{~g}$ ) respectively. Administration of $250 \mathrm{mg} / \mathrm{kg} \mathrm{L}$. cupanioides extract to the constipated rats significantly normalized ( $p<$ $0.05)$ their body weight gain $(8.15 \mathrm{~g})$ and gastrointestinal ratio $(87.75)$ compared to the constipated control. Serum levels of ACP and AST were significantly elevated $(p<0.05)$ in the 150 and $250 \mathrm{mg} / \mathrm{kg}$ dose groups compared to controls while ALP witnessed reduction. However, there was no alteration in the levels of GGT and LDH across all groups.

Conclusion: The aqueous root extract of $L$. cupanioides possesses laxative activity in loperamideinduced constipated rats.
\end{abstract}

Keywords: Constipation, Lecaniodiscus cupanioides, Gastrointestinal transit ratio, Loperamide, Bisacodyl

Tropical Journal of Pharmaceutical Research is indexed by Science Citation Index (SciSearch), Scopus, International Pharmaceutical Abstract, Chemical Abstracts, Embase, Index Copernicus, EBSCO, African Index Medicus, JournalSeek, Journal Citation Reports/Science Edition, Directory of Open Access Journals (DOAJ), African Journal Online, Bioline International, Open-J-Gate and Pharmacy Abstracts

\section{INTRODUCTION}

Constipation is a functional gastro-intestinal disorder affecting $8-15 \%$ of the general population [1], characterized by infrequent or difficult evacuation of feces [2]. The menace has a substantial impact on morbidity and quality of life, which may be characterized by unexplained abdominal pain, discomfort and bloating in association with altered bowel habits [3]. The use of synthetic drugs such as senna, correctol, exlax, senokot, bisacodyl and gaviscon is very common as a means of treating constipation.

The use of these orthodox drugs is however, limited due to their cost and undesirable side 
effects [4]. Consequently, most of the affected persons rely on herbal preparations for the treatment of the disorder [5]. Some medicinal plant extracts are known to exhibit antispasmodic effects by stimulating water absorption in the intestine [6]. Apart from being fast acting, cheap and readily available, the users of medicinal plants for the treatment of constipation also believe that they have some control in their choice of medication.

Lecaniodiscus cupanioides Planch belongs to the family Sapindaceae. It is a small tree 6-12 $\mathrm{m}$ high branching low down with a widely spreading crown. It is identified by various local names in Nigeria such as akika (Yoruba), kafi-nama-zaki (Hausa), okpu (Igbo), and utantan (Edo) [7]. The plant is ethno-medically reported to be useful in the treatment of wounds and sores, abdominal swelling caused by liver abscess, fever, measles, and hepatomegaly as well as burns [8]. The central nervous system (CNS) depressant action of the plant has also been demonstrated [8]. Despite the wide traditional usage of the herb as a laxative [9], there is no scientific report to substantiate this claim. Therefore, the present study was designed to evaluate the laxative activity of the aqueous root extract of $L$. cupanioides in loperamide - induced constipated rats and the effect was compared with bisacodyl, a reference laxative drug.

\section{EXPERIMENTAL}

\section{Drugs and chemicals}

Loperamide hydrochloride was purchased from Lusomedicaments S.A. Queluz de Balxo, Portugal, while carboxymethylcellulose and carmine were products of BDH Chemicals Ltd. Poole, England. Bisacodyl was obtained from Medrel Pharmaceuticals Ltd, India and all enzyme kits were from Clinica Applicada, S.A., Spain.

\section{Plant materials}

Fresh mature roots of Lecaniodiscus cupanioides was obtained from Oja Oba, Ilorin, Kwara State, Nigeria in October 2013. It was identified and authenticated by Mr. A. Boluwatife of the Department of Plant Biology, University of Ilorin, Nigeria and voucher specimen (UIL 235) was deposited in the University of Ilorin herbarium.

\section{Preparation of aqueous root extract}

The roots of $L$. cupanoides were cut into pieces, washed thoroughly with distilled water and dried on the laboratory bench. The dried pieces were milled into powder and $200 \mathrm{~g}$ of the material was extracted by shaking for $24 \mathrm{~h}$ in $1200 \mathrm{~mL}$ of distilled water using Labcon Platfrom shaker (Maraisburg, South Africa). The resulting infusion was decanted, filtered and evaporated to dryness on water bath. This was reconstituted in distilled water to give the required doses of 50, 150 and $250 \mathrm{mg} / \mathrm{kg}$ body weight used for the experiment.

\section{Animals}

Male Wistar rats with an average weight of $127 \mathrm{~g}$ were obtained from the small animal holding unit of Department of Biochemistry, University of Ilorin, Nigeria. The animals were housed in clean metabolic cages placed in a well ventilated house. They were acclimatized to the animal house condition for 7 days during which they were allowed free access to commercial pelleted rat chow (Bendel feeds and flour mill Ltd, Edo State, Nigeria) and water. All experimental procedures were performed in compliance with international policies governing the humane and ethical treatment of experimental animals as contained in the United States National Institutes of Health (NIH) guidelines [10] after ethical approval by the University of Ilorin (UIL/13/017).

\section{Induction of constipation in the rats}

Constipation was induced in the animals by the oral administration of $0.5 \mathrm{~mL}$ of loperamide (3 $\mathrm{mg} / \mathrm{kg}$ body weight daily for 3 days) [11], while the control rats were administered with distilled water only. The passage of reduced, hard and dry fecal pellets indicated constipation in the rats on the 4 th day.

\section{Experimental design}

The rats were divided into six groups of five rats each. The animals in Group 1 (control) and Group 2 (constipated control) were administered with distilled water orally. Groups 3, 4 and 5 comprised constipated rats administered 50, 150 and $250 \mathrm{mg} / \mathrm{kg}$ body weight per day of root extract of L. cupanoides respectively while Group 6 were constipated rats administered bisacodyl (0.21 mg/kg body weight) [12]. All oral administration was done using metal oropharyngeal cannula. The water and feed intake, number of faecal pellets and body weight gain of all the rats were recorded during experimental period.

Determination of total number, dry weight and water content of faecal pellets

The excreted faecal pellets of individual rats were collected every day at $10.00 \mathrm{~h}$ throughout 
the duration of the experiment for 7 days. The total number, weight and water content of the pellets were determined. The water content was calculated as the difference between the wet and dry weights of the pellet [11].

\section{Preparation of serum}

Briefly, under halothane anaesthesia, rats were made to bleed through their cut jugular veins which were slightly displaced (to prevent blood contamination by interstitial fluid) into clean, dry centrifuge tubes. This was centrifuged at $1282 \mathrm{~g}$ for 5 min using Hermle Bench Top Centrifuge (Model Hermle, Z300, Hamburg, Germany). The sera were later aspirated with Pasteur pipettes into sample bottles and used for the assay of serum enzymes.

\section{Determination of gastrointestinal transit (GIT) ratio}

GIT ratio was measured according to the method described by [11]. On the 7th day, $1 \mathrm{~mL}$ of carmine (3 g suspended in $50 \mathrm{~mL}$ of $0.5 \%$ carboxymethylcellulose) was orally administered to the rats. One hour after administering carmine, the animals were sacrificed and their small intestines were quickly removed. The distance over which the carmine had travelled and the total length of the small intestine were measured. The GIT ratio was expressed as the percentage of the distance travelled by the carmine relative to the total length of the small intestine.

\section{Determination of serum enzymes}

The procedure of Tietz et al [13] was adopted for the determination of serum acid phosphatase, alkaline phosphatase, aspartate aminotransferase, $\quad$-glutaryltransferase and lactate dehydrogenase activities.

\section{Statistical analysis}

Data were expressed as means \pm SEM of four replicates and were subjected to one way analysis of variance (ANOVA) followed by
Bonferroni tests to determine significant differences in all the parameters. All data were analysed using GraphPad Prism 5 statistical package (GraphPad Software, San Diego MA, USA) and values were considered statistically significant at $p<0.05$.

\section{RESULTS}

Table 1 shows the effect of Loperamide on feed and water intake, fecal properties and body weight of constipated rats before treatment. Loperamide significantly $(p<0.05)$ reduced the number of faecal pellets and increased significantly $(p<0.05)$ the body weight of the constipated rats compared to the normal rats. This was an indication of constipation. However, there was no significant difference $(p>0.05)$ between feed intake, water intake and water content of faecal pellets, that of the control and that of the constipated animals.

The effect of aqueous extract of $L$. cupanioides on feed and water intake, body weight gain and faecal properties of constipated rats after treatment is shown in Table 2. There was no significant difference $(p>0.05)$ in the feed and water intake and number of faecal pellets in all the animals. However, the body weight and water in faecal pellets of the constipated rats changed significantly $(p<0.05)$ compared to the normal control. This alteration was counteracted by the administration of aqueous root extract of $L$. cupanioides to the animals.

Figure 1 shows the effect of the aqueous root extract of $L$. cupanioides on gastrointestinal transit ratio in loperamide-induced constipated rats. At all doses tested, the administration of the extract of $L$. cupanioides to constipated rats significantly increased $(p<0.05)$ gastrointestinal motility compared to the constipated control and it compares favourably well with bisacodyl, the standard drug used in this study.

Table 1: Effect of Loperamide on feed and water intake, faecal properties and weight of constipated rats before treatment

\begin{tabular}{lcc}
\hline Parameters & Normal rats & Constipated rats \\
\hline Feed intake $(\mathrm{g})$ & $15.56 \pm 0.67$ & $13.46 \pm 0.79$ \\
Water intake $(\mathrm{mL})$ & $28.63 \pm 2.77$ & $29.97 \pm 1.97$ \\
Number of faecal pellet & $54.06 \pm 1.22$ & $45.43 \pm 3.16^{*}$ \\
Water content of faecal pellets $(\mathrm{mL})$ & $2.75 \pm 0.10$ & $2.25 \pm 0.09$ \\
Weight of animals $(\mathrm{g})$ & $124.45 \pm 1.33$ & $135.38 \pm 0.89^{*}$ \\
\hline
\end{tabular}

Data are mean \pm SEM values $(n=4) ;{ }^{*}$ significantly different from normal control at $p<0.05$ 
Table 2: Effect of aqueous extract of $L$. cupanioides on feed and water intake, body weight gain and fecal properties of constipated rats on day 7

\begin{tabular}{lccccc}
\hline Groups & Feed intake $(\mathbf{g})$ & $\begin{array}{c}\text { Water intake } \\
(\mathbf{m L})\end{array}$ & $\begin{array}{c}\text { No of faecal } \\
\text { pellets }\end{array}$ & $\begin{array}{c}\text { Water in faecal } \\
\text { pellets }(\mathbf{m L})\end{array}$ & $\begin{array}{c}\text { Body weight } \\
\text { gain }(\mathbf{g})\end{array}$ \\
\hline Normal control & $13.94 \pm 0.87$ & $30.63 \pm 1.26$ & $59.25 \pm 1.36$ & $2.94 \pm 0.41$ & $11.38 \pm 1.53$ \\
Constipated & $15.06 \pm 0.83$ & $28.13 \pm 0.63$ & $58.69 \pm 2.17$ & $2.13 \pm 0.33^{\mathrm{a}}$ & $19.45 \pm 2.38^{\mathrm{a}}$ \\
C + $50 \mathrm{mg} / \mathrm{kg}$ & $15.06 \pm 0.45$ & $30.63 \pm 1.01$ & $58.88 \pm 2.47$ & $2.50 \pm 0.53^{\mathrm{a}}$ & $12.38 \pm 1.41^{\mathrm{b}}$ \\
C + $150 \mathrm{mg} / \mathrm{kg}$ & $14.44 \pm 0.92$ & $30.13 \pm 1.60$ & $60.25 \pm 1.57$ & $2.94 \pm 0.33$ & $10.28 \pm 1.28^{\mathrm{b}}$ \\
C + $250 \mathrm{mg} / \mathrm{kg}$ & $14.63 \pm 0.32$ & $28.69 \pm 0.56$ & $61.5 \pm 4.53$ & $2.38 \pm 0.42^{\mathrm{a}}$ & $8.15 \pm 1.33^{\mathrm{b}}$ \\
C + Bisacodyl & $14.44 \pm 0.85$ & $29.69 \pm 2.03$ & $61.88 \pm 2.33$ & $3.13 \pm 0.22^{\mathrm{b}}$ & $15.13 \pm 1.66^{\mathrm{ab}}$ \\
\hline
\end{tabular}

Data are mean \pm SEM values $(n=4)$; ${ }^{a}$ significantly different $(P<0.05)$ compared to the normal control,

${ }^{b}$ significantly different $(P<0.05)$ compared to constipated control

Table 3: Effect of oral administration of aqueous extract of $L$. cupanioides on some serum enzymes in normal and loperamide-induced constipated rats

\begin{tabular}{lccccc}
\hline Group & ACP (U/L) & ALP (U/L) & AST (U/L) & V-GT (U/L) & LDH (U/L) \\
\hline Normal control & $1.07 \pm 0.04$ & $1.38 \pm 0.04$ & $1.03 \pm 0.02$ & $0.12 \pm 0.01$ & $0.10 \pm 0.03$ \\
Constipated & $1.08 \pm 0.02$ & $1.89 \pm 0.07^{\mathrm{a}}$ & $1.53 \pm 0.04^{\mathrm{a}}$ & $0.08 \pm 0.02$ & $0.13 \pm 0.05$ \\
C + 50 mg/kg & $0.74 \pm 0.02$ & $1.44 \pm 0.05^{\mathrm{b}}$ & $1.24 \pm 0.02$ & $0.10 \pm 0.01$ & $0.15 \pm 0.04$ \\
C + 150mg/kg & $1.82 \pm 0.07^{\mathrm{b}}$ & $1.26 \pm 0.04^{\mathrm{b}}$ & $1.42 \pm 0.07^{\mathrm{a}}$ & $0.05 \pm 0.00$ & $0.21 \pm 0.09$ \\
C + 250mg/kg & $1.68 \pm 0.06^{\mathrm{b}}$ & $0.64 \pm 0.03^{\mathrm{ab}}$ & $2.03 \pm 0.06^{\mathrm{ab}}$ & $0.07 \pm 0.01$ & $0.20 \pm 0.11$ \\
C + Bisacodyl & $0.68 \pm 0.02$ & $1.07 \pm 0.03^{\mathrm{b}}$ & $0.83 \pm 0.02$ & $0.12 \pm 0.01$ & $0.17 \pm 0.01$ \\
\hline
\end{tabular}

Data are mean \pm SEM values $(n=4)$. ${ }^{a}$ significantly different $(p<0.05)$ compared to the normal control, ${ }^{b}$ significantly different $(p<0.05)$ compared to constipated control

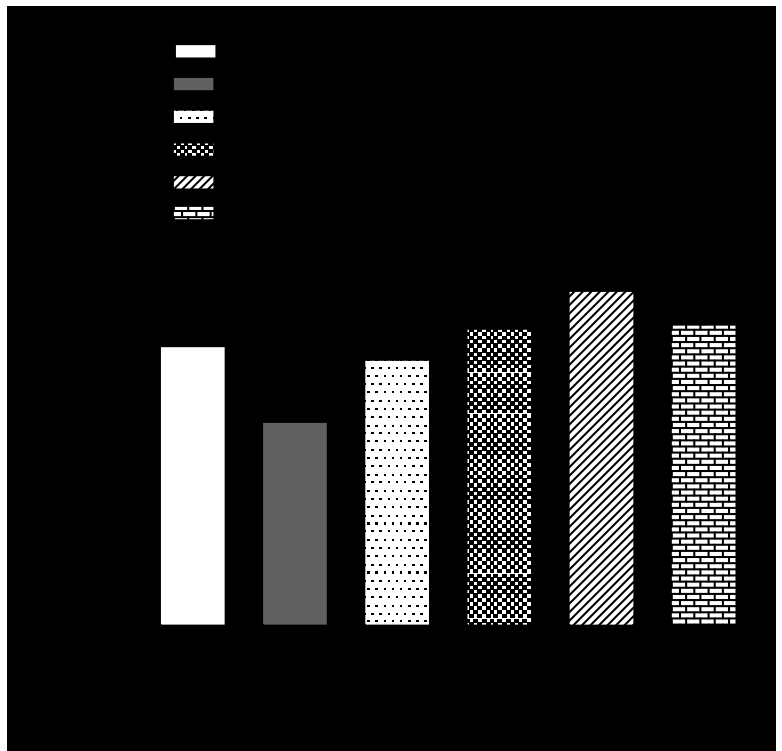

Fig 1: Effect of aqueous extract of $L$. cupanioides on gastrointestinal transit ratio in loperamide-induced constipated rats. Data are mean $\pm \operatorname{SEM~}(n=5)$; ${ }^{a}$ significantly different from normal control $(p<0.05)$, ${ }^{b}$ significantly different from constipated control $(p<$ 0.05)

The effect of the administration of the aqueous extract of $L$. cupanioides on some serum enzymes' activities is shown in Table 3 . There were significant differences $(p<0.05)$ in the serum acid phosphatase, alkaline phosphatase and aspartate aminotransferase among the groups of animals. However, the 50 and 150 $\mathrm{mg} / \mathrm{kg}$ extract-treated groups seemed to improve these parameters better than the $250 \mathrm{mg} / \mathrm{kg}$.
The activities of lactate dehydrogenase and $\mathrm{Y}$ glutaryltransferase in the extract treated groups were not significantly different $(p>0.05)$ from the normal control and bisacodyl-treated constipated rats.

\section{DISCUSSION}

The use of herbal remedies in the treatment of constipation is a common practice in many countries of the world [14]. The present study has clearly demonstrated that the aqueous extract of $L$. cupanioides has laxative activity; which is comparable to bisacodyl, a standard laxative drug. Loperamide has been documented to induce constipation in wistar rat by inhibiting intestinal water secretion and colonic peristalsis. This inhibition extends faecal evacuation time and delays intestinal luminal transit. Loperamideinduced constipation is therefore considered to be a model of spastic constipation [15].

The observed reduction in the number of faecal pellets and weight following treatment with loperamide indicated induction of constipation in the rats. This observation was also reported in previous studies [16]. However, loperamide did not prevent the animals from feeding adequately [11]. The administration of the extract of $L$. cupanioides to the constipated rats was effective in normalizing defecation frequency, body weight gain, faecal volume and motility of the colon. These are indications of the laxative property of the plant extract. This may be due to the 
presence of natural anthraquinone derivatives constituent of the root extract [17] which has been implicated to have laxative effects. This compound possibly exerts its action by disturbing the equilibrium between the absorption of water from the intestinal lumen via an active sodium transport and the secretion of water into the lumen by prostaglandin dependent mechanism [18].

Although the feed intake did not differ among the groups, the gain in body weight was higher in the untreated constipated rats compared to the extract treated groups. This may be due to the accumulation of faecal pellets in their bodies, thus accounting for the extra weight [19]. Similar observation was reported by Niwa et al [19], where dietary fibre was used for the treatment of morphine-induced constipation in rats.

The transit process of the entire gastrointestinal tract reflected the overall gastrointestinal motor activity. Measuring colonic transit time is useful in constipation, abdominal bloating and refractory irritable bowel syndrome. It also provides quantitative information about colonic movement which enables the identification and characterization of transit abnormalities and allows assessment of the severity of the problem as well as the response to therapy [20]. In this study, carmine was the marker used to measure the colonic movement. The extract increased intestinal motility which, in turn, enhanced colonic peristalsis in the rats. The possible mechanism of action of the extract in this process may be by enhancing the release of fluid thereby increasing intestinal secretion. The laxative effect of the extract could also be attributed to changes in the intestinal motility, which produced an increase in intestinal transit and colonic movement [21]. Generally, the effect of the treatment with the extract compared favourably well to that of bisacodyl. This is an indication that the herb was effective in ameliorating bowel obstruction, thereby enhancing easy movement in the intestine.

There are many enzymes such as phosphatases, dehydrogenases and transferases that are found in appreciable quantities in the serum which did not actually originate from the extracellular fluid. It is only during tissue damage that these enzymes leak out of the tissues and become elevated in the serum, making them marker enzymes for safety and or toxicity of pharmacological agents [22]. Acid phosphatase $(A C P)$ is a marker enzymes of lysosomal membrane while alkaline phosphatase (ALP) is found in the plasma membrane and endoplasmic reticulum. Aspartate aminotransferase is localized in the cells of the liver, kidney and the heart [23]. The observed increase in the serum aspartate aminotransferase and acid phosphatase at higher dosages may be due to altered membrane permeability [24]. The reduction in the serum alkaline phosphatase may be attributed to the inactivation of the enzyme molecules [25]. However, fluctuations in the activities of these enzymes at some dosages only signify subtle changes in the metabolic processes of the animals.

\section{CONCLUSION}

The present study points to a laxative effect in loperamide-induced constipated rats by $L$. cupanioides. It is however, important to note that the laxative activity was dose-dependent and compares favourably with that of bisacodyl. These findings have lent scientific support to the folkloric use of $L$. cupanioides as a laxative. However, caution should be taken in the prolonged usage of the extract as it could cause some metabolic changes.

\section{ACKNOWLEDGEMENT}

The authors are grateful to the Department of Biochemistry, University of llorin for providing a conducive environment for the performance of this study.

\section{REFERENCES}

1. Talley NJ, Stanghellini $V$, Heading $R C$, Koch $K L$, Malagelada JR, Tytgat GNJ. Functional gastroduodenal disorders. Gut 1999; 45(2): 11371142.

2. Higgins PDR, Johanson JF. Epidemiology of constipation in North America: a systematic review. Am J Gastroenterol 2004; 99(4): 750-759.

3. Thompson WG, Longstreth GF, Drossman DA, Heaton KW, Irvine EJ, Muller-Lissner SA. Functional bowel disorders and functional abdominal pain. Gut 1999; 45(2): 1143-1147.

4. Erasto P, Adebola PO, Grierison DS, Afolayan AJ. An ethnobotanical study of plants used for the treatment of diabetes in Eastern Cape Province. South Afr J Biotech 2005; 4:1458-1460.

5. Calixto JB. Efficacy, safety, quality control, marketing and regulatory guidelines for herbal medicines (phytotherapeutic agents). Brazilian J Medical Biol Res 2000; 33: 179-189.

6. Palombo EA. (2006). Phytochemicals from traditional medicinal plants used in the treatment of Diarrhoea: Mode of action and effects on intestinal function. Phytother Res 2006; 20: 717-724. 
7. Keay RWJ, Onochie CFA, Standfield DP. Trees of Nigeria. Revised version, Clarendon Press, Oxford, London, 1989, Pp. 361 - 362.

8. Yemitan OK, Adeyemi OO. CNS depressant activity of Lecaniodiscus cupanioides, Fitoterapia 2005; 76 (5): 412-418.

9. Adesegun SA, Coker HAB, Hamann, MT. Antifungal triterpenoid saponins for Lecaniodiscus cupanioides. Res J Phytochem 2008; 2(2): 93-99

10. National Institute of Health. Guide for the care and use of laboratory animals. NIH publication no. 85-23, Bethesda, USA, 1985

11. Wintola OA, Sunmonu TO, Afolayan AJ. The effect of Aloe ferox Mill. in the treatment of loperamideinduced constipation in Wistar rats. BMC Gastroenterol 2010; 10: 95

12. Adams WJ, Meagher AP, Lubowski DZ, King DW. Bisacodyl reduces the volume of polyethylene glycol solution required for bowel preparation. Dis Colon Rectum 1994; 229-234

13. Tietz NW, Prude EL, Sirgard-Anderson O. Tietz Textbook of clinical chemistry. 2nd edition, W.B. Saunders Company, London. 1994; p.1354.

14. Van Wyk BE, Van Oudtshoorn B, Gericke N. Medicinal plants of South Africa, Briza Publication, Pretoria, South Africa, 1997.

15. Takasaki K, Kishibayashi N, Ishii A, Karasawa A. Effects of $K W-5092$, a novel gastroprokinetic agent, on the delayed colonic propulsion in rats. Jpn J Pharmacol 1994; 65:67-71.

16. Shimotoyodome A, Meguro S, Hase T, Tokimitsu I, Satake $T$. Decreased colonic mucus in rats with loperamide-induced constipation. Comp Biochem Physiol 2000; 126:203-211
17. Nafiu MO, Abdulsalam TA, Akanji MA. Phytochemical Analysis and Antimalarial Activity Aqueous Extract of Lecaniodiscus cupanioides Root. J Tropic Med 2013; $1-4$.

18. Collier HOJ, Mcdonald-Gibson WJ, Sated SA. Stimulation of prostaglandin biosynthesis by drugs: effects in vitro of some drugs affecting gut function. Br J Pharmacol 1976; 58:193-198.

19. Niwa T, Nakao M, Hoshi S, Yamada K, Inagaki K, Nishida M, Nabeshima T. Effect of Dietary Fiber on Morphine-induced constipation in Rats. Biosci Biotechnol Biochem 2002; 66(6): 1233-1240.

20. Degan L. Gastrointestinal motility-physiology and methods of measurement. Ther Umsch 2007; 64(4): 195-199.

21. Capasso F, Mascolo N, Autore G, Duraccio MR. Effect of indomethacin on aloin and 1, 8 dioxianthraquinoneinduced production of prostaglandins in rat isolated colon. Prostaglandins 1983; 26: 557-562.

22. Pendota SC, Yakubu MT, Grierson DS, Afolayan AJ. Effect of administration of Hippobromus pauciflorus leaves in male Wistar rats. Afr J Trad CAM 2010; 7(1): 40-46.

23. Akanji MA, Yakubu MT, Kazeem MI. Hypolipidemic and toxicological potential of aqueous extract of Rauvolfia vomitoria Afzel root in wistar rats. J Med Sci 2013; 13(4): 253-260.

24. Reichling JJ, Kaplan MM. Clinical use of serum enzymes in liver disease. Digestive Dis Sci 1988; 33: 1601 1614

25. Kaplan LA, Pesce AJ: Clinical Chemistry: Theory, Analysis and Correlation, Vol. 8, 3rd ed. Mosby, London, 1996, pp 140-152. 